\title{
Dye-sensitized solar cells using fresh and dried natural dyes
}

\author{
Sofyan A. Taya ${ }^{1, *}$, Taher M. El-Agez ${ }^{1}$, Hatem S. El-Ghamri ${ }^{1}$, Monzir S. Abdel-Latif ${ }^{2}$ \\ ${ }^{1}$ Physics Department, Islamic University of Gaza, Gaza, Palestinian Authority \\ ${ }^{2}$ Chemistry Department, Islamic University of Gaza, Gaza, Palestinian Authority
}

\section{Email address:}

staya@iugaza.edu.ps (S. A. Taya), telagez@iugaza.edu.ps (T. M. El-Agez), hghamri@iugaza.edu.ps (H. S. El-Ghamri), mlatif@iugaza.edu.ps (M. S. Abdel-Latif)

\section{To cite this article:}

Sofyan A. Taya, Taher M. El-Agez, Hatem S. El-Ghamri, Monzir S. Abdel-Latif. Dye-Sensitized Solar Cells Using Fresh and Dried Natural Dyes, International Journal of Materials Science and Applications. Vol. 2, No. 2, 2013, pp. 37-42.

doi: 10.11648/j.ijmsa.20130202.11

\begin{abstract}
Different natural dye extracts have been prepared and used as sensitizers in the fabrication of dye-sensitized solar cells (DSSCs). These dyes have been extracted from both fresh and dried raw materials. The absorption spectra of these dyes have been investigated by UV-VIS spectrophotometry. DSSCs were assembled using $\mathrm{TiO} 2$ and $\mathrm{ZnO}$ nanostructured, mesoporous films. Photovoltaic parameters such as short circuit current density Jsc, open circuit voltage Voc, fill factor FF, and overall conversion efficiency $\eta$ for the fabricated cells were determined under $100 \mathrm{~mW} / \mathrm{cm} 2$ illumination. The immersion time of the nanocrystalline-TiO2 electrode in spinach extract and the temperature at which this process occurs were optimized. The optimal dying temperature is found to be $60{ }^{\circ} \mathrm{C}$ and the efficiency of the DSSC is found to saturate to $0.29 \%$ after $12 \mathrm{hr}$ of soaking in the dye solution.
\end{abstract}

Keywords: Dye-Sensitized Solar Cell, $\mathrm{ZnO}, \mathrm{TiO}_{2}$, Natural Dyes

\section{Introduction}

Dye-sensitized solar cells (DSSCs) were first proposed by Grätzel et al. in the early 1990's. They developed a DSSC with energy conversion efficiency exceeding $7 \%$ in 1991 [1] and $11.4 \%$ in 2001 [2] by combining nanostructured electrodes to efficient charge injection dyes. A DSSC is the third generation photovoltaic device for low cost conversion of solar energy into electrical energy. DSSCs have received an increasing interest due to the simple fabrication process and relatively high conversion efficiency. The principle of operation of DSSCs is based on sensitization of a wide band-gap metal oxide semiconductor to the visible light region by an adsorbed molecular dye. When the metal oxide semiconductor film is immersed in the dye, a monolayer of the dye is anchored onto its surface. Excitation of atoms by sun light occurs in the dye and the photogenerated charges are separated at the interface between the dye and metal oxide. Nanostructured metal oxide semiconducting materials are usually used in the fabrication of DSSC [3] due to the large surface area they offer for dye anchoring [4]. The charge transport is highly affected by the crystalline quality of metal oxide material, therefore it is important to reduce the charge traps in the films to speed up charge transport [5]. The amount of light entering the DSSC and the photocurrent extraction are determined by the transparent electrode. In the fabrication of DSSCs, the choice of the metal oxide material and the transparent electrode is crucial to obtain efficient light harvesting, charge separation, and extraction. $\mathrm{TiO}_{2}$ has been widely studied for efficient DSSCs [6-8], and a power conversion efficiency of $11 \%$ was reported [2]. Moreover, $\mathrm{ZnO}$ nanoparticles were investigated for DSSCs [9-11]. DSSCs fabricated using $\mathrm{ZnO}$ nanoparticles have achieved the second highest efficiency after $\mathrm{TiO}_{2}[12]$.

Another crucial parameter in the fabrication of DSSCs is the sensitizing dye. Due to the dye significant role, considerable interest has been directed towards the development and improvement of new families of organic dyes and of metal complexes. So far, the most efficient dye is found to be $\mathrm{Ru}(\mathrm{II})[13,14]$ and Os(II) [15]. These complexes have a number of interesting features such as good absorption, long excited lifetime, and highly efficient metal-to-ligand charge transfer. The disadvantages of these complexes are high cost and sophisticated preparation techniques. Therefore, alternative organic dyes such as natural dyes have been studied intensively. The main features of natural dyes 
are their availability, environmental friendly and low in cost.

In this work, natural dyes were extracted from fresh and dried leaves of anethum graveolens, parsley, arugula, spinach oleracea, and green algae. These extracted dyes were characterized by UV-VIS absorption spectra. The photovoltaic properties of the fabricated DSSCs using these extracts as sensitizers were investigated. Moreover, the immersion time of the $\mathrm{TiO}_{2}$ electrode in spinach oleracea dye solution and the temperature at which this process occurs were studied in details.

\section{Experiment}

\subsection{Preparation of Natural Dye Sensitizers}

Five types of plant leaves were used: anethum graveolens, parsley, arugula, spinach oleracea, and green algae. Before drying, the leaves were washed with distilled water, dried at $60{ }^{\circ} \mathrm{C}$, and then immersed in absolute ethanol at room temperature in the dark for $24 \mathrm{hr}$ to extract the dyes. Other leaves of the same plants are left to dry for one week at room temperature. After drying and crushing into fine powder using a mortar, the dyes are extracted again in the same procedure. The solids were filtered out, and the filtrates were concentrated at $60{ }^{\circ} \mathrm{C}$ for the use as sensitizers.

\subsection{Preparation of Dye-Sensitized Solar Cells}

FTO conductive glass sheets with sheet resistance of 15 $\Omega /$ sq and transmission $>80 \%$ (Xinyan Tech. Ltd, Hong Kong) were first cleaned in a detergent solution using an ultrasonic bath for $15 \mathrm{~min}$, rinsed with water and ethanol, and then dried. $\mathrm{TiO}_{2}$ paste was prepared by adding $50 \mathrm{mg}$ of $\mathrm{TiO}_{2}$ nanopowder 10-25 nm (US Research Nanomaterial, Inc, USA) to $50 \mathrm{mg}$ of polyethylene glycol then grinding the mixture for half an hour until a homogeneous paste was obtained. The paste was deposited on the FTO conductive glass by doctor-blade technique in order to obtain a $\mathrm{TiO}_{2}$ layer of $0.25 \mathrm{~cm}^{2}$ area. The $\mathrm{TiO}_{2}$ layer was preheated at $60{ }^{\circ} \mathrm{C}$ for $20 \mathrm{~min}$ and then sintered at $450{ }^{\circ} \mathrm{C}$ for $40 \mathrm{~min}$. After cooling down to $60{ }^{\circ} \mathrm{C}$, the samples were immersed in the natural extracts for $24 \mathrm{~h}$. The dyed $\mathrm{TiO}_{2}$ layer and a sputtered platinum counter electrode were assembled to form a solar cell by sandwiching a redox $\left(\mathrm{I}^{-} / \mathrm{I}^{3}\right)$ electrolyte solution. The electrolyte solution is composed of $2 \mathrm{ml}$ acetonitrile $(\mathrm{ACN}), 8 \mathrm{ml}$ propylene carbonate (p-carbonate), $0.668 \mathrm{gm}(\mathrm{LiI})$, and $0.0634 \mathrm{gm}\left(\mathrm{I}_{2}\right)$.

\subsection{Measurements}

The UV-VIS absorption spectra of all dyes before and after drying were measured using a UV-VIS spectrophotometer (Thermoline Genesys 6). The absorption spectra analysis was carried out in the wavelength range from 350 to $800 \mathrm{~nm}$. The I-V characteristic curves under illumination were conducted using National Instruments data acquisition card (USB NI 6251) in combination of a Labview program. The I-V curves were measured at $100 \mathrm{~mW} / \mathrm{cm}^{2}$ irrad- iations using high pressure mercury arc lamp.

\section{Results and Discussion}

\subsection{Absorption of Natural Dyes}

The representative UV-VIS absorption spectra for the extracts of parsley, arugula, spinach oleracea, green algae, and anethum graveolens have been investigated. Figures 15 show the UV-VIS absorption spectra of these extracts dissolved in ethyl alcohol. The most striking feature that has been observed from these figures is that parsley, arugula, green algae, and anethum graveolens extracts have almost the same absorption peak in the visible region at 666 $\mathrm{nm}$. Moreover, this peak does not depend on whether the extract is taken from the leaves after or before drying. Extract of spinach oleracea shows an absorption peak at 701 nm.

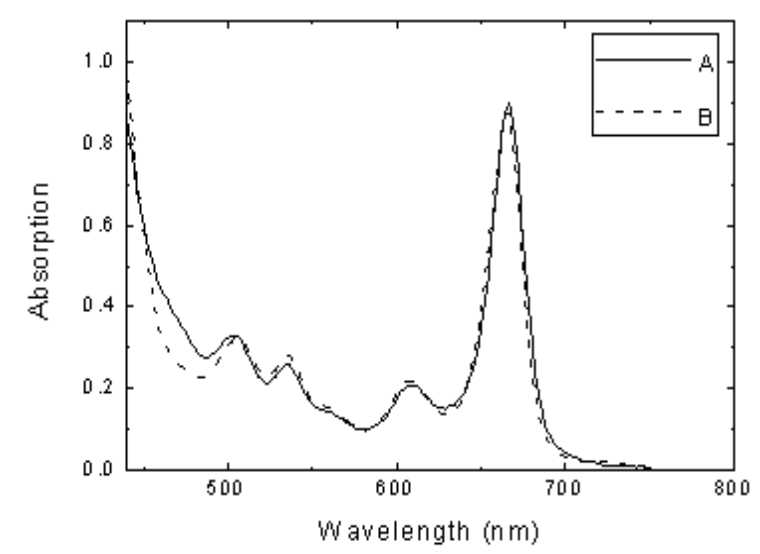

Figure 1. Absorption spectrum of the extract of parsley leaves. A: after drying, B: before drying.

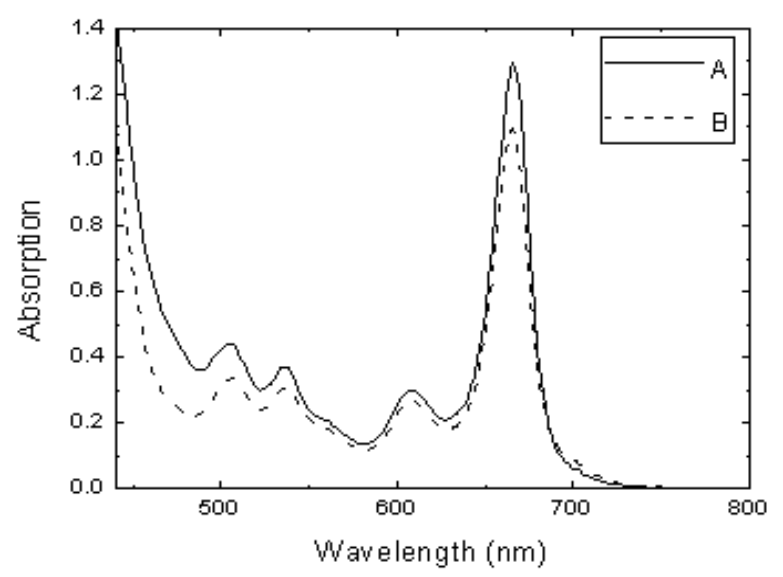

Figure 2. Absorption spectrum of the extract of arugula (cress) leaves. A: after drying, B: before drying. 


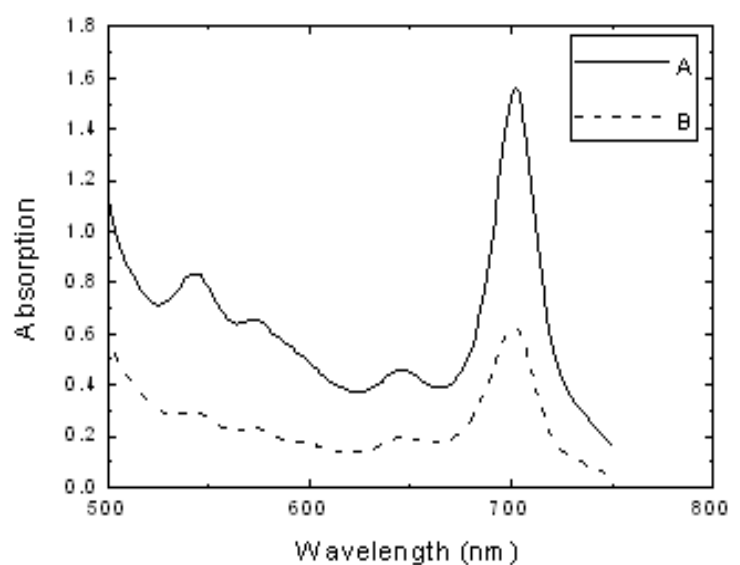

Figure 3. Absorption spectrum of the extract of spinach oleracea. A: after drying, $B$ : before drying.

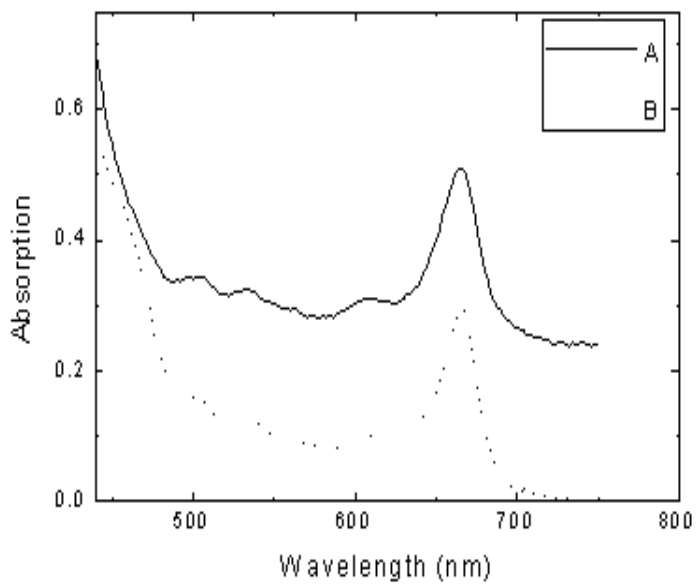

Figure 4. Absorption spectrum of the extract of green algae. A: after drying, B: before drying.

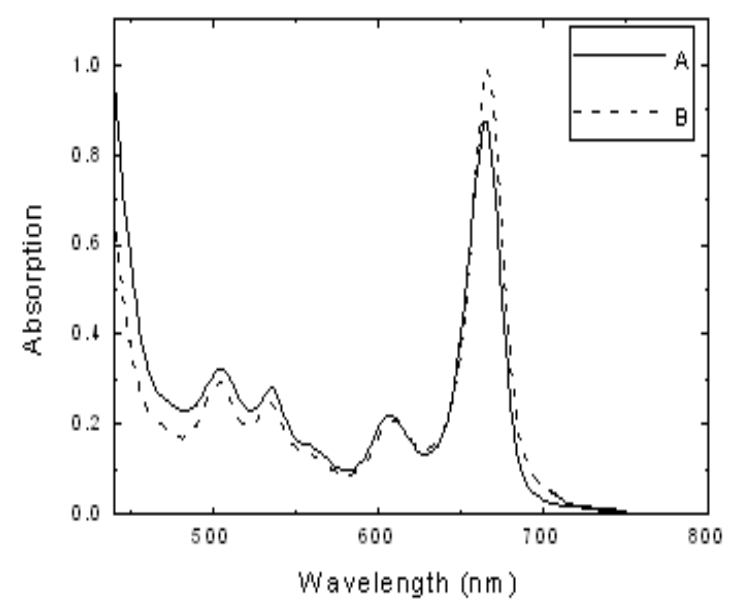

Figure 5. Absorption spectrum of the extract of anethum graveolens. A: after drying, $B$ : before drying.

\subsection{Photoelectrochemical Properties}

Photovoltaic tests of the fabricated DSSCs using these natural dyes as sensitizers were performed by measuring the $\mathrm{I}-\mathrm{V}$ curve of each cell under irradiation with white light $(100 \mathrm{~mW} / \mathrm{cm} 2)$ from a high pressure mercury arc lamp. The performance of natural dyes as sensitizers in DSSCs was evaluated by short circuit current (Jsc), open circuit voltage (Voc), fill factor (FF), and energy conversion efficiency $(\eta)$. Figures $6-10$ show the typical I-V curves of the DSSCs using the sensitizers extracted from anethum graveolens, parsley, arugula, spinach oleracea, and green algae. As can be seen from these figures, the performance of the DSSCs is crucially dependent on the sensitizing dye. Some of the used dyes exhibit better performance after drying and others before drying. Concerning short circuit current, higher values were obtained after drying the dye in case of spinach oleracea, and green algae. However, higher values of open circuit voltage were obtained after drying the dye in case of parsley and green algae. The DSSC output power was calculated as $\mathrm{P}=\mathrm{I} \mathrm{V}$ using the I-V data. In Fig. 11, we show as an example the calculated power as a function of $\mathrm{V}$ for the DSSC sensitized by spinach oleracea. The maximum power (Pmax) of the DSSCs for each cell is then obtained. The current (Imp) and the voltage (Vmp) corresponding to the maximum power point are then obtained. All the photoelectrochemical parameters of the DSSCs sensitized with natural dyes are listed in Table 1. As displayed in Table 1, the fill factor of the fabricated DSSC ranges between $21 \%$ and $46 \%$. The Voc changes from 0.416 to $0.599 \mathrm{~V}$ and the Jsc varies from 0.134 to 1.11 $\mathrm{mA} / \mathrm{cm} 2$. The best performance was obtained from the DSSC sensitized by the spinach oleracea extract after drying where the efficiency of the cell reached $0.29 \%$. These results are similar to those of the DSSCs sensitized by other natural dyes in previous works $[16,17]$. It is clear from Table 1 that some dyes exhibit higher conversion efficiency after drying whereas others have better performance before drying. The DSSCs sensitized with the extracts of parsley, spinach oleracea, and green algae show higher efficiencies when using the dyes after drying. Moreover, Table 1 shows the photoelectrochemical parameters of the DSSCs sensitized with $\mathrm{Ru}$ complexcis-dicyano-bis(2,2'-bipyridyl-4,4'dicarboxylic acid) ruthenium(II), Ruthenizer 505, ( Solaronix, Switzerland), which is widely used in DSSCs. As can be seen, Voc of the DSSC using the spinach oleracea extract as sensitizer is comparable to that of the DSSC sensitized by Ru complex.

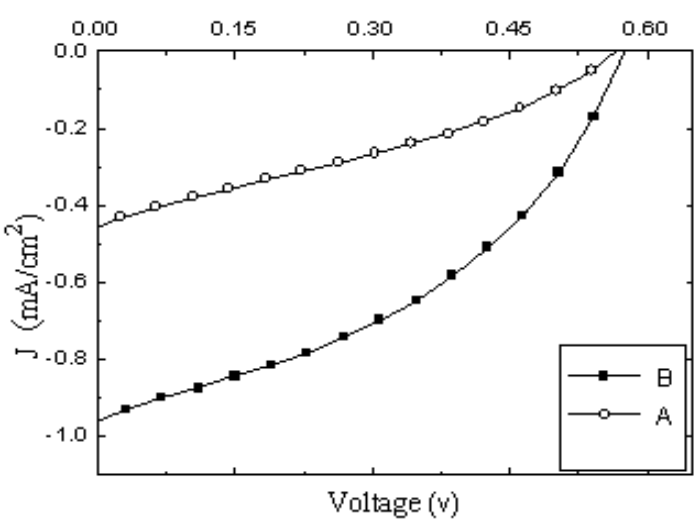

Figure 6. I-V curves for the DSSC sensitized by anethum graveolens. A: after drying, B: before drying. 


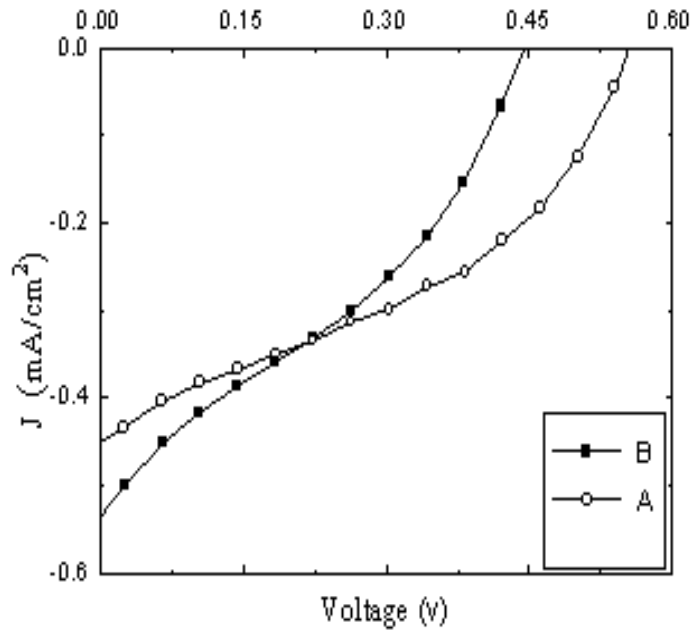

Figure 7. I-V curves for the DSSC sensitized by parsley. A: after drying, B: before drying.

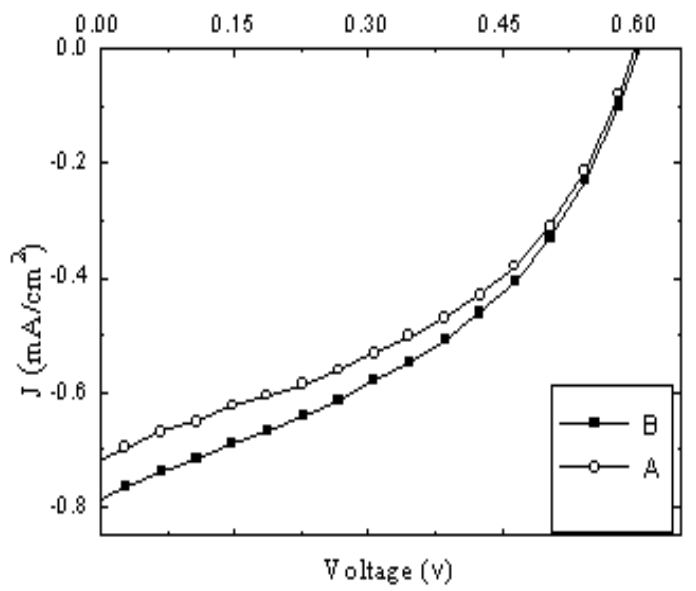

Figure 8. I-V curves for the DSSC sensitized by arugula (cress). A: after drying, B: before drying.

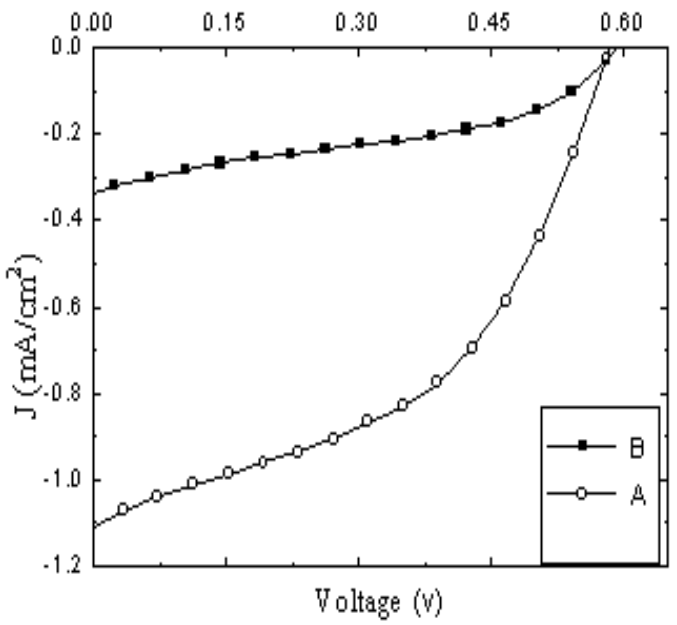

Figure 9. I-V curves for the DSSC sensitized by spinach oleracea. A: after drying, $B$ : before drying.

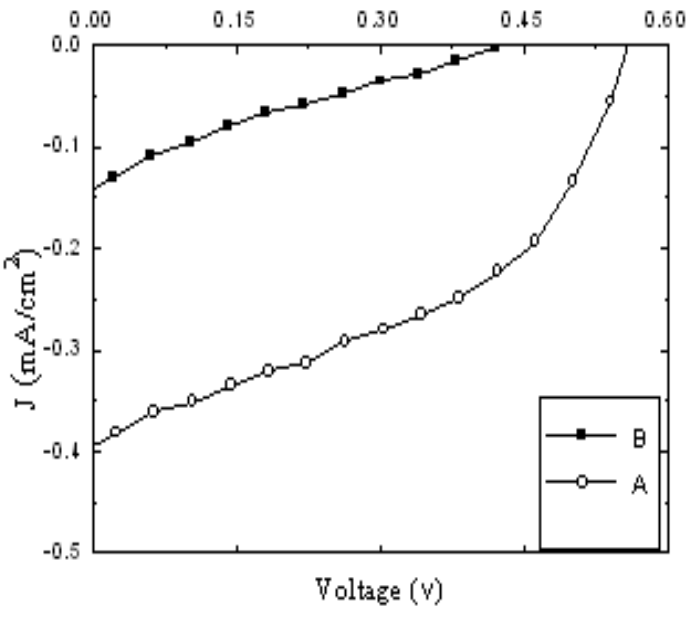

Figure 10. I-V curves for the DSSC sensitized by green algae. A: after drying, $B$ : before drying.

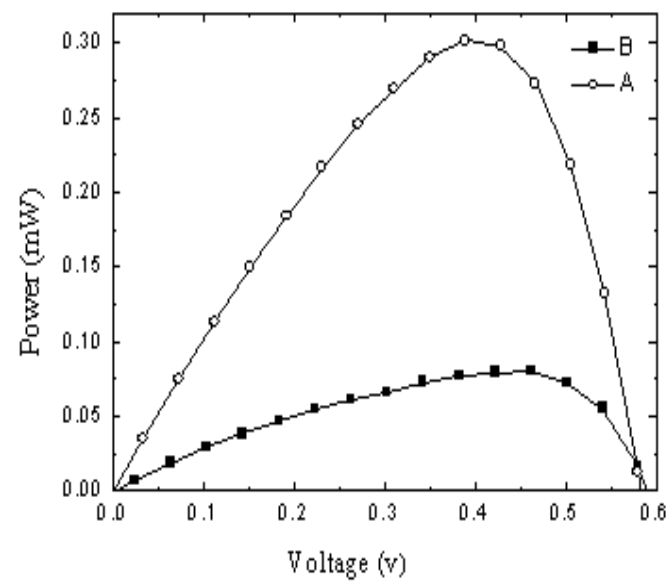

Figure 11. Power-voltage curves for the DSSC made of $\mathrm{TiO}_{2}$ electrode in spinach extract. A: after drying, B: before drying.

Table 1. Photoelectrochemical parameters of the DSSCs sensitized by various natural dyes. A: after drying, B: before drying.

\begin{tabular}{|c|c|c|c|c|c|c|c|}
\hline Dye & $\begin{array}{l}\mathbf{J}_{\mathrm{sc}} \\
\left(\mathrm{mA} / \mathrm{cm}^{2}\right)\end{array}$ & $\begin{array}{l}\mathbf{V}_{\text {oc }} \\
(\mathbf{V})\end{array}$ & $\begin{array}{l}\mathbf{J}_{\mathrm{m}} \\
\left(\mathbf{m A} / \mathbf{c m}^{2}\right)\end{array}$ & $\begin{array}{l}V_{m} \\
(V)\end{array}$ & $\begin{array}{l}\mathbf{P}_{\mathrm{m}} \\
(\mathrm{mW})\end{array}$ & $\begin{array}{l}\text { FF } \\
\%\end{array}$ & $\begin{array}{l}\mathbf{H} \\
\%\end{array}$ \\
\hline \multicolumn{8}{|l|}{ anethum } \\
\hline graveolens (B) & 0.965 & 0.579 & 0.622 & 0.365 & 0.227 & 40 & 0.22 \\
\hline $\begin{array}{l}\text { anethum } \\
\text { graveolens (A) }\end{array}$ & 0.454 & 0.562 & 0.229 & 0.362 & 0.080 & 32 & 0.08 \\
\hline parsley (B) & 0.535 & 0.445 & 0.281 & 0.285 & 0.079 & 34 & 0.07 \\
\hline parsley (A) & 0.448 & 0.553 & 0.259 & 0.378 & 0.097 & 40 & 0.09 \\
\hline arugula (B) & 0.788 & 0.599 & 0.509 & 0.389 & 0.196 & 42 & 0.20 \\
\hline arugula (A) & 0.713 & 0.594 & 0.467 & 0.389 & 0.180 & 43 & 0.18 \\
\hline \multicolumn{8}{|l|}{ spinach } \\
\hline oleracea (B) & 0.332 & 0.590 & 0.176 & 0.459 & 0.083 & 42 & 0.08 \\
\hline $\begin{array}{l}\text { spinach } \\
\text { oleracea (A) }\end{array}$ & 1.11 & 0.583 & 0.775 & 0.387 & 0.301 & 46 & 0.29 \\
\hline green algae (B) & 0.134 & 0.416 & 0.052 & 0.223 & 0.011 & 21 & 0.01 \\
\hline green algae (A) & 0.397 & 0.559 & 0.245 & 0.386 & 0.095 & 44 & 0.10 \\
\hline $\mathrm{Ru}$ & 12 & 0.621 & 9.78 & 0.373 & 3.65 & 49 & 3.65 \\
\hline
\end{tabular}


$\mathrm{ZnO}$ electrodes were prepared from $\mathrm{ZnO}$ powder with an approximate nanoparticle size of $50 \mathrm{~nm}$ (MTI Corporation, USA). The $\mathrm{ZnO}$ paste was prepared by adding $50 \mathrm{mg}$ of $\mathrm{ZnO}$ and $50 \mathrm{mg}$ of polyethylene glycol and then grinding the mixture for half an hour until a homogeneous paste was obtained. Thin layers of nanocrystalline $\mathrm{ZnO}$ were spread on the transparent conducting FTO coated glass using doctor blade method and were placed in an oven at $60{ }^{\circ} \mathrm{C}$ for $20 \mathrm{~min}$. Finally, the samples were sintered at $450{ }^{\circ} \mathrm{C}$ for 40 min. Samples were then cooled to $60^{\circ} \mathrm{C}$ before being dyed with the extract of spinach oleracea for $24 \mathrm{hr}$ under dark. The DSSC is then assembled as described in section 2.2. Table 2 shows the results obtained for $\mathrm{TiO}_{2}$ and $\mathrm{ZnO}$ electrodes. The efficiencies obtained with $\mathrm{TiO}_{2}$ are much higher than those for $\mathrm{ZnO}$ substrates, in agreement with the general trends observed for these two substrate materials [17].

Table 2. Photoelectrochemical parameters of the DSSCs based on $\mathrm{TiO}_{2}$ and $\mathrm{ZnO}$ electrodes and sensitized by spinach oleracea.

\begin{tabular}{llllllll}
\hline Electrode & $\begin{array}{l}\mathbf{J}_{\mathbf{s c}} \\
\left(\mathbf{m A} / \mathbf{c m}^{2}\right)\end{array}$ & $\begin{array}{l}\mathbf{V}_{\text {oc }} \\
(\mathbf{V})\end{array}$ & $\begin{array}{l}\mathbf{J}_{\mathbf{m}} \\
\left(\mathbf{m A} / \mathbf{c m}^{2}\right)\end{array}$ & $\begin{array}{l}\mathbf{V}_{\mathbf{m}} \\
(\mathbf{V})\end{array}$ & $\begin{array}{l}\mathbf{P}_{\mathbf{m}} \\
(\mathbf{m W})\end{array}$ & $\begin{array}{l}\mathbf{F F} \\
\mathbf{\%}\end{array}$ & $\begin{array}{l}\mathbf{H} \\
\mathbf{\%}\end{array}$ \\
\hline $\mathrm{TiO}_{2}$ & 1.11 & 0.583 & 0.775 & 0.387 & 0.301 & 46 & 0.29 \\
$\mathrm{ZnO}$ & 0.123 & 0.226 & 0.065 & 0.101 & 0.008 & 20 & 0.008 \\
\hline
\end{tabular}

\subsection{Optimization of Dying Temperature and Time}

The performance of the DSSC is crucially dependent on many parameters. Among these parameters are the temperature at which the dying process occurs and the time of immersion of the electrode layer in the dye solution. We here optimize these two parameters. After spreading the $\mathrm{TiO}_{2}$ paste on the FTO coated glass and sintering at $450{ }^{\circ} \mathrm{C}$ for $40 \mathrm{~min}$, the samples were divided into six groups. Each group was immersed in the extract of spinach oleracea at a specific temperature. Dying temperatures that have been considered are $30,40,50,60,70$, and $80{ }^{\circ} \mathrm{C}$. The photovoltaic properties of the DSSCs sensitized by the extract of spinach oleracea dyes at different temperatures were studied by measuring I-V curves, and the corresponding photoelectrochemical parameters are calculated. Figure 12 shows the DSSC efficiency as a function of the dying temperature. As observed from the figure, the efficiency is enhanced with increasing the dying temperature from $30{ }^{\circ} \mathrm{C}$ to $60{ }^{\circ} \mathrm{C}$ and then it declines towards lower values with further increasing of the temperature. A dying temperature of $60{ }^{\circ} \mathrm{C}$ could be used as an optimal value.

Moreover, we optimize the time of immersion of the electrode layer in the dye solution. Seven sets of samples of $\mathrm{TiO}_{2}$ layer on FTO were prepared. Each set was immersed in the extract of spinach oleracea for a specific time. A set was immersed for two hours, another set for four hours, and so on. Figure 13 illustrates the efficiency of the fabricated DSSCs as a function of the immersion time of $\mathrm{TiO}_{2}$ electrode in the dye solution. The efficiency of the cell increases with increasing the time and saturates after 12 hours of immersion. Increasing the dying time more than 12 hours does not have a significant impact on the efficiency.

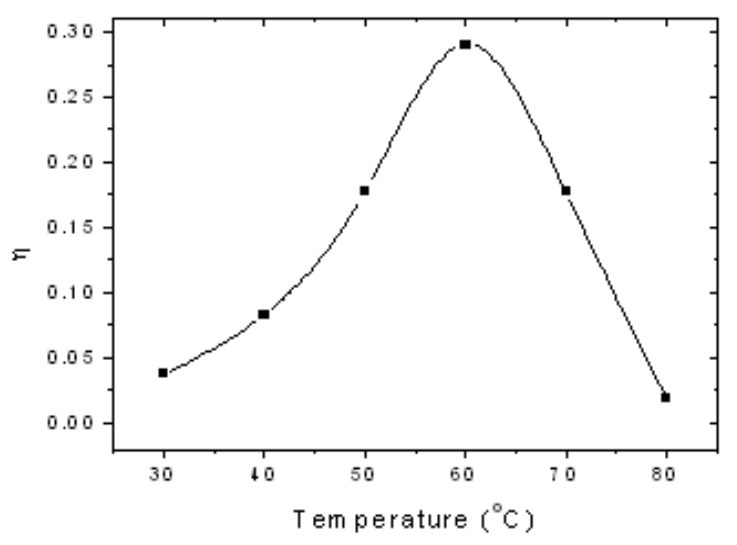

Figure 12. DSSC efficiency versus the dying temperature of $\mathrm{TiO}_{2}$ film sensitized with spinach.

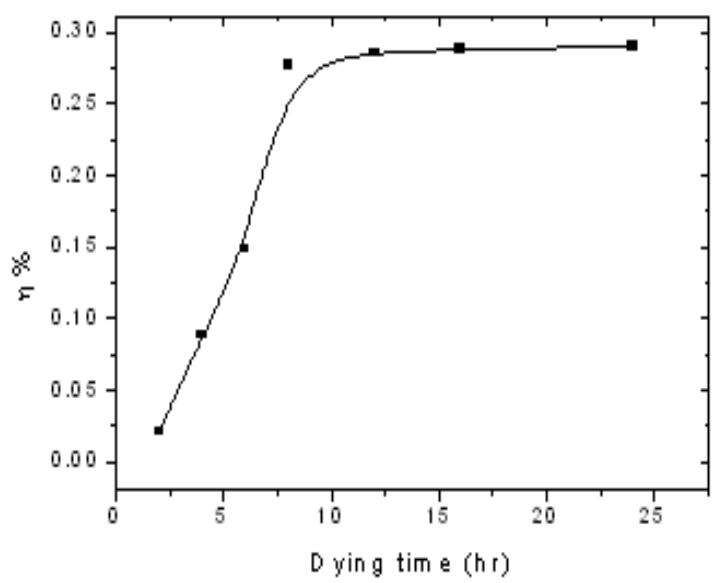

Figure 13. DSSC efficiency versus the time of electrode immersion in the dye solution.

\section{Conclusions}

In this paper, dye-sensitized solar cells (DSSCs) were assembled using extracts from five plant leaves as sensitizers for nanocrystalline $\mathrm{TiO}_{2}$ photoelectrodes. The leaves were used as sensitizers before and after drying. Photovoltaic parameters of the fabricated DSSCs were determined under $100 \mathrm{~mW} / \mathrm{cm}^{2}$ illumination. It is found that some of the used dyes exhibit better performance after drying and others before drying with the best performance was obtained from the DSSC sensitized by the spinach oleracea extract after drying where the efficiency of the cell reached $0.29 \%$. The results revealed that $\mathrm{V}_{\mathrm{oc}}$ of the DSSC using the spinach oleracea extract as sensitizer is comparable to that of the DSSC sensitized by Ru complex. The efficiencies obtained with $\mathrm{TiO}_{2}$ as a semiconducting layer are much 
higher than those for $\mathrm{ZnO}$ substrates. The efficiency of the DSSC is enhanced with increasing the dying temperature from $30{ }^{\circ} \mathrm{C}$ to $60{ }^{\circ} \mathrm{C}$ and then it declines towards lower values with further increasing of the temperature. The efficiency of the DSSC increases with increasing the immersion time of the electrode layer in the dye solution and saturates after 12 hours of immersion. Increasing the dying time more than 12 hours does not have a significant impact on the efficiency.

\section{Acknowledgements}

This work was supported by the scientific research affairs at the Islamic university of Gaza for the academic year 2011-2012.

\section{References}

[1] B. O'Regan and M. Grätzel, "A low-cost, high-efficiency solar cell based on dye-sensitized colloidal TiO2 films," Nature, vol. 353, pp. 737-740, 1991.

[2] M. Nazeeruddin, P. Péchy, T. Renouard, S. Zakeeruddin, R. Humphry-Baker, P. Comte, P. Liska, L. Cevey, E.Costa, V. Shklover, L. Spiccia, G. Deacon, Bignozzi and M. Grätzel, "Engineering of Efficient Panchromatic Sensitizers for Nanocrystalline TiO2-Based Solar Cells," ACS Publications, J. Am. Chem. Soc., vol. 123, pp. 1613-1624, 2001.

[3] H. Chen, Z. Duan, Y.G. Lu and A. D. Pasquier, "Dyesensitized solar cells combining $\mathrm{ZnO}$ nanotip arrays and nonliquid gel electrolytes," MINERALS METALS \& MATERIALS SO-CIETY, Journal of ELECTRONIC MATERIALS, Vol. 38, pp.1612-1617, 2009.

[4] M.K. Nazeeruddin, A. Kay, I. Rodicio, R. Humphrybaker, E. Muller, P. Liska, N. Vlachopoulos, and M.A. Grätzel, J. Am. Chem. Soc., vol. 115, pp. 6382-6387, 1993.

[5] M. Law, L.E. Greene, J.C. Johnson, R. Saykally, and P. Yang, Nat. Mater., vol. 4, pp. 455, 2005.

[6] U. Bach, D. Lupo, P. Comte, J. E. Moser, F. Weissortel and J. Salbeck, "Solidstate dye-sensitized mesoporous TiO2 solar cells with high photon-to-electron conversion efficiencies," Nature, vol. 395, pp. 583-585, 1998.

[7] A. J. Frank, N. Kopidakis and J. van de Lagemaat "Electrons in nanostructured $\mathrm{TiO} 2$ solar cells: transport, recombi- nation and photovoltaic properties," Coordination Chem. Rev., vol. 248, pp. 1165-1179, 2004.

[8] A. N. M. Green, E. Palomares, S. A. Haque, J. M. Kroon and J. R. Durrant, "Charge transport versus recombination in dye-sensitized solar cells employing nanocrystalline $\mathrm{TiO} 2$ and $\mathrm{SnO} 2$ films," J. Phys. Chem. B, vol. 109, pp.12525$12533,2005$.

[9] H. Rensmo, K. Keis, H. Lindstrom, S. Sodergren, A. Solbrand and A. Hagfeldt, "High light-to-energy conversion efficiencies for solar cells based onnanostructured $\mathrm{ZnO}$ electrodes," J. Phys. Chem. B, vol. 101, pp. 2598-2601, 1997.

[10] Z. Longyue, D. Songyuan, X. Weiwei, W. Kongjia, "DyeSensitized Solar Cells Based on ZnO Films," IOPS-cience, Plasma Science \& Technology, vo1.8, pp.172-175, 2006.

[11] T. El-Agez, A. El Tayyan, A. Al-Kahlout, S. Taya, M. Abdel-Latif, "Dye-sensitized solar cells based on ZnO films and natural dyes," International Journal of Materials and Chemistry, vol. 2, pp.105-110, 2012.

[12] K. Keis, E. Magnusson, H. Lindstrom, S.E. Lindquist and A Hagfeldt, Sol. Energy Mater. Sol. Cells, vol. 73, pp. 51-56, 2002.

[13] M.K. Nazeeruddin, P. Pechy, P. Liska, T. Renouard, S.M. Zakeeruddin, R. Humphry-Baker, P. Comte, L. Cevey, E. Costa, V. Shklover, L. Spiccia, G.B. Deacon, C.A. Bignozzi, M. Graetzel, "Engineering efficient panchromatic sensitizers for nanocrystalline TiO2-based solar cells," J. Am. Chem. Soc., vol. 123, pp. 1613-1624, 2001.

[14] P. Wang, C. Klein, R. Humphry-Baker, S.H. Zakeeruddin and M.A Graetzel, "High Molar extinction coefficient sensitizer for stable dye-sensitized Solar Cells," J. Am. Chem. Soc., vol.127, pp. 808-809, 2005.

[15] S. Altobello, R. Argazzi, S. Caramori, C. Contado, S. Da Fre, Rubino, C. Chone, G. Larramona and C.A. Bignozzi, "Sensitization of nanocrystalline $\mathrm{TiO} 2$ with black absorbers based on os and Ru polypyridine complexes," J. Am. Chem. Soc., vol. 127, pp. 15342-15343, 2005.

[16] H. Zhou, L. Wu, Y. Gao and T. Ma, "Dye-sensitized solar cells using 20 natural dyes as sensitizers," Journal of Photochemistry and Photobiology A: Chemistry, vol. 219, pp. 188-194, 2011.

[17] N.M. Gómez-Ortíz, I.A. Vázquez-Maldonado, A.R. PérezEspadas, G.J. Mena-Rejón and J.A.Azamar-Barrios, G.Oskam, Solar Energy Materials, vol. 94, pp. 40-44, 2010. 